\title{
Evaluating Impact of Tax Burden on State Financial Stability: Empirical Research of EU Countries
}

\author{
Simonas Skarzauskas \\ Mykolas Romeris University, Vilnius, Lithuania \\ Email: simonas.skarzauskas@gmail.com
}

How to cite this paper: Skarzauskas, S. (2021). Evaluating Impact of Tax Burden on State Financial Stability: Empirical Research of EU Countries. Theoretical Economics Letters, 11, 1122-1139. https://doi.org/10.4236/tel.2021.116071

Received: September 28, 2021

Accepted: December 4, 2021

Published: December 7, 2021

Copyright (อ 2021 by author(s) and Scientific Research Publishing Inc. This work is licensed under the Creative Commons Attribution International License (CC BY 4.0).

http://creativecommons.org/licenses/by/4.0/ (c) (i) Open Access

\begin{abstract}
The available literature on the relationship between the tax burden and financial stability is mixed, although some consensus exists on the negative effects of some taxes on economic growth. Since 2008, policymakers have striven to identify the financial vulnerabilities and to avoid the mistakes that led to the Great Financial Crisis. Various scholars studying the impact of tax burden focus on different aspects and generate controversial conclusions therefore a comprehensive methodology for assessing all types of factors and testing this methodology in the European Union (EU) context is lacking. Based on the analysis of scientific sources this paper presents a theoretical model that causally combines the components of tax burden and state financial stability. The newly constructed index was used to assess tax burden and the applicability of the index was verified by assessing the impact of tax burden on state financial stability in the $28 \mathrm{EU}$ countries during the 2005-2019 period. According to the results of the empirical study (regression analysis), the increase in tax burden strengthened state financial stability in three country groups (High Tax Burden/Low Financial Stability; Low Tax Burden/High Financial Stability; Low Tax Burden/Low Financial Stability), while decreased in the High Tax burden/High Financial stability country group.
\end{abstract}

\section{Keywords}

Financial Stability, Tax Burden, Impact, Index Calculation Methodology

\section{Introduction}

The implications of the degree of taxation on financial equilibrium have been 
analysed in many recent studies. It is often considered, that the impact of tax burden is implicit on economic growth, on the capacity to provide the necessary resources for public finance and on the quality of financial system services. The international scientific community is actively researching the factors influencing state financial stability and agrees that an evaluation should be based on a macroeconomic and systemic approach. Assessing the impact of the tax burden on the state's financial stability is particularly relevant in shaping a country's tax policy, and its significance has become apparent in the context of the recent financial crisis. The European Union's ambitious goals for economic and social development are closely linked to the process of reforming the tax system. EU is made up of countries in different stages of economic development that calculate taxes on the basis of differing principles. This provides real opportunities for researchers to study the interrelations between tax burden parameters and national economic development trends. The optimal tax burden is seen as an important condition for social development, the quality of public welfare, business growth, while the efficiency of the tax system is one of the most important factors determining the potential of the national economy (Abuselidze, 2012). Modern economists argue that reducing tax burden effectively influences state financial stability and stimulates the economy (Alstadsaeter et al., 2017; Tamai \& Myles, 2019; Celikay, 2020), but there is no consensus among scholars on how tax cuts affect economic development in the long run (Vasiliauskaitė \& Stankevičius, 2009). In addition, the empirical evidence is clearly mixed, depending on several characteristics of each study, such as countries, period, methodology or explicative variables. The existing models do not give a clear answer about the impact of the tax burden, as some results are contradictory to others. A comprehensive methodology for assessing all types of factors and testing this methodology in the European Union context is lacking.

In this paper, we studied the relationship between taxation and state financial stability for European Union in 2005-2019 through a regression approach to detect different patterns along with countries groups. A clustering of the EU countries according to the differing tax rate policies and financial stability level was performed using the Ward method of hierarchical clustering. This methodology enhanced the possibility to analyse the phenomenon taking into account differences in the distribution as countries with high/low level of tax rate and high/low financial stability can exhibit variance of results. The major contribution of the paper is the development of the complex relationship model between tax burden and state financial stability and verification of the model in $28 \mathrm{EU}$ countries during the 2005-2019 period. By designing the model, the assumptions that create the conditions for the state financial stability were examined and identified, the analysis of the tax burden and the components and indicators of the state financial stability was performed, and an index assessing the impact of the tax burden was constructed and tested. 


\section{Theoretical Aspects of Financial Stability and Its' Conceptual Model}

Financial stability is widely studied in the scientific literature and the concept differs depending on the scientist's approach. The international scientific community is actively researching the factors influencing state financial stability (Adam et al., 2015; Roosma et al., 2015; Cural \& Cevik, 2015; Flood et al., 2016; Bischof et al., 2019). However, as Schinasi (2006: p. 1) points out, "the practice of financial-stability analysis is still in its infancy when compared with, for example, the analysis of monetary stability or macroeconomic stability", meaning there is a lack of a commonly used model or an analytical system to assess financial stability. By some authors financial stability is perceived as the absence of fluctuations (Gadanetz et al., 2012; Das et al., 2019); as the absence of crises and tensions (Haldane et al., 2017; Bischof, Laux, \& Leuz, 2019; Ozili, 2020). A broader approach to financial stability is promoted (Houben \& Kakes, 2004; Schinasi, 2006; Fell \& Schinasi, 2005) and it is argued that financial stability is an extensive concept encompassing various aspects of finance and financial systems. Financial stability manifests itself through the ability to reallocate resources, manage risk and overcome financial imbalances. According to these authors, financial stability can be assessed in terms of the consequences to the real sector of the economy and is perceived as a continuum. Modern economists (Levine \& Corbae, 2018; Akins et al., 2016; Ozili \& Thankom, 2018; Jiang \& Levine, 2019) place emphasis on the interplay between financial system stability and sustainable economic growth, fiscal policy and financial system (Boyd et al., 2005; Kroszner et al., 2007; Dell'Ariccia et al., 2008; Amadeo, 2013; Caner et al., 2010; Staniuliene, 2015). Financial stability could also be assessed through sets of macro indicators covering the various sectors of business, household, financial and finance markets (Schakeldorf et al., 2011; Hawkins \& Klau, 2000; Nelson \& Perli, 2007; Gray et al., 2007).

Although narrower approaches to financial stability are characterized by simplicity such as the absence of certain phenomena (Gadanetz et al., 2012; Haldane et al., 2017; Das et al., 2019) a broader assessment, encompassing public finance, financial systems, economic growth and fiscal policy, provides an opportunity to reveal the essence of this phenomenon more accurately and is in line with the objectives of this paper. By focusing on the broader concept of financial stability (Fell \& Schinasi, 2005; Houben et al., 2005; Levine \& Corbae, 2018; Akins et al., 2016; Ozili \& Thankom, 2018; Jiang \& Levine, 2019), the state financial stability in this paper is defined as the interaction between the stability of public finances, the stability of the financial system and balanced economic growth. Such a perception of state financial stability was chosen as a theoretical starting point for theoretical and empirical research as it creates preconditions for a complex assessment of this phenomenon, with a special focus given to the complex interrelations between these areas (Figure 1). 


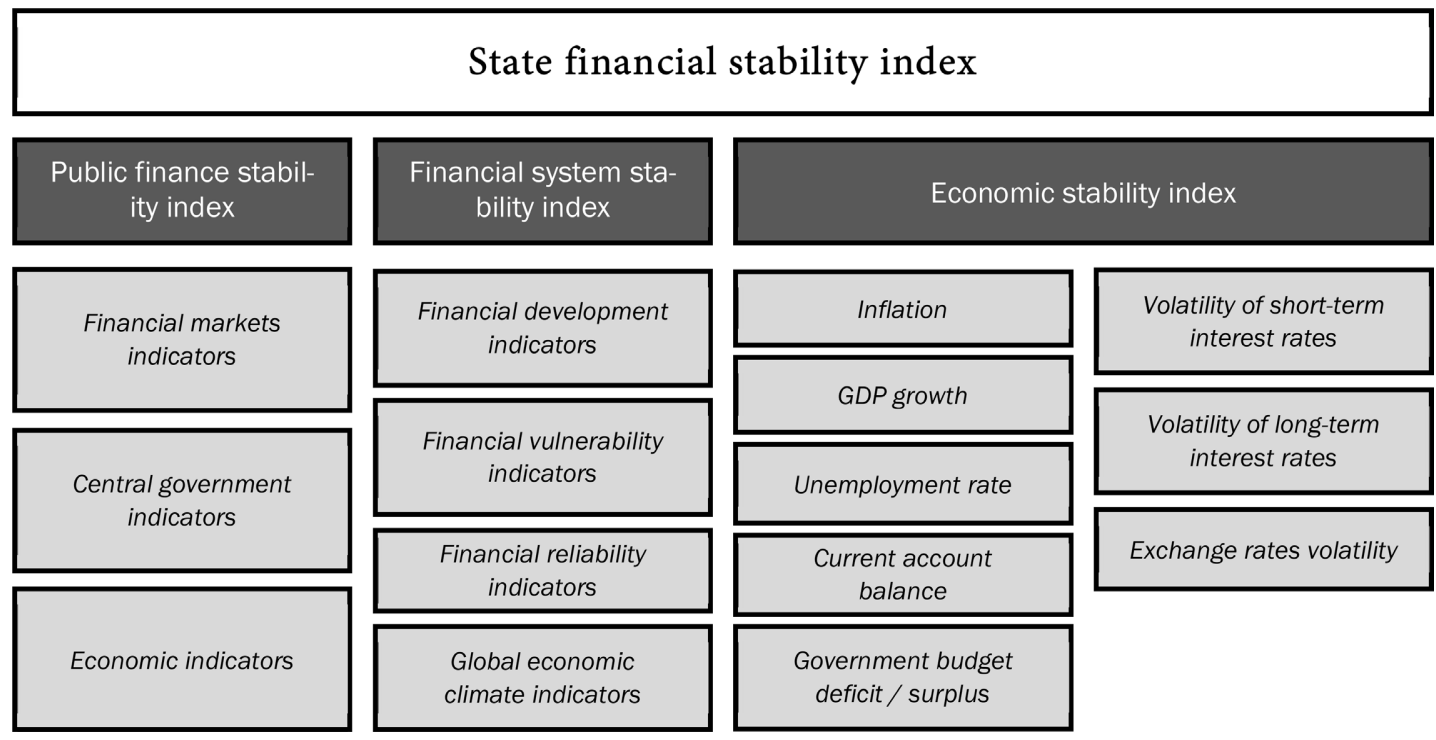

Figure 1. The structure of the State Financial Stability Index (compiled by author).

Commenting on Figure 1, the stability of public finances in this paper is treated as the totality of the stability of financial markets and economic indicators, which is decisively influenced by the actions of the central government. After analysing the valuation methods for the evaluation of public finances (Blommestein \& Turner, 2012; Ilgun, 2016; Janda \& Kravtsov, 2017; Birskyte, 2019; Alshubiri, 2019), the Trading Economics Index was chosen as, in the author's opinion, it corresponds the closest to the concept of public finance stability formed in this paper. The structure of the Public Financial Stability Index is based on the classification proposed by Trading Economics (Fedec, 2009), which consists of 1) financial market indicators, 2) central government indicators, and 3) economic indicators. The structure of the Financial System Stability Index was chosen based on the analysis of scientific sources (Skarzauskas, 2016) and theoretical models of such authors as Gersl and Hermanek (2006), Van den End (2006), Albulescu $(2010,2012)$, as well as the empirical studies evaluating the financial systems of Czech Republic, Romania, Turkey and other countries. The set of indicators proposed by Albulescu (2010) illustrates the spectrum of financial stability dimensions, which consists of 4 sub-indices such as 1) the developmental stage of the financial system; 2) financial vulnerability; 3) financial reliability; 4) the global economic climate. Each sub-index in the structure is reflected with a range of indicators. The structure of the Economic Stability Index is based on Daugèliené (2012), Riley (2009, 2014), Sharuddin and Rama (2017) and others' theoretical insights, which the author has aggregated into seven key indicators (see Figure 1) reflecting the macroeconomic situation. The weight of the indicators was determined according to the analysed scientific sources and based on the factors that have the greatest impact on economic stability. This number of indicators is relatively optimal compared to other high-volume indices and the combination of indicators includes key influencing factors. Structure 
of indices and weights assigned to indicators are provided in appendices. It is important to note that the factors listed are closely linked, therefore the stability of the financial system can only be ensured by the stability of all these components together. For these reasons, financial stability analysis is a particularly difficult and complex task.

\section{The Problematic Aspects of Tax Burden Assessment}

Research shows that international tax burden comparisons are possible, but the impact of tax burdens on a country's financial stability remains problematic primarily due to the multifaceted nature of the interaction (Salaudeen \& Atoyebi, 2018; Celikay, 2020). Based on the scientific analysis performed, two channels of tax burden impact on state financial stability were identified: through tax structure (Yanikkaya \& Turan, 2018; Durusu-Ciftci, Gokmenoglu, \& Yetkiner, 2018; Valenduc, 2019; Bunn \& Asen, 2020) and trough taxation level (Karagianni et al., 2012; Mao, 2017; Milasi \& Waldman, 2018; Bösenberg, Egger, \& Zoller-Rydzek, 2018). In summary, the predictions from the theoretical models are mixed, and the available empirical evidence is controversial. Hence, further empirical studies are required in this field.

The most commonly used method in research for tax burden calculation is the ratio of tax revenue to GDP (OECD, 2019; Liu \& Altshuler, 2013; Celikay, 2020; Vasileva, 2020; Paientko \& Oparin, 2020). The popularity of this method is based on the simplicity of the calculation and the availability of data through national statistical agencies and departments. The indicator of tax revenue to GDP can also be based on qualitative studies assessing the dependence of this indicator and GDP through economic activity. However, in this article other method of tax burden assessment was selected-construction of composite Tax burden index. This assessment approach fundamentally differs from calculation of tax burden ratio, which is mentioned before, because it includes relatively wide range of indicators, large volume of data and enables to assess influence of tax burden comprehensively. Based on literature analysis composite Tax burden index is based on three main tax groups: corporate, labor and consumption (see Figure 2). Calculation methods for subindices of these tax groups were chosen after detailed analysis during which advantages and limitations of various composite indices were identified. Corporate tax burden assessment was based on set of indicators proposed by Keller and Schanz (2013). Indicators in this set measures size of tax rates (6 indicators), quality and effectiveness of tax system ( 3 indicators), regulatory of taxes ( 5 indicators) and burden of tax administration (1 indicator). Burden from taxes on labor was calculated using set of indicators proposed by Kotlán \& Machová (2012a, 2012b) which includes net personal average tax rate, top personal tax rate threshold and average wage ratio, average rate of social security contribution and burden of tax administration. Finally, taxes on consumption tax consist of consumption tax rate, consumption tax base and tax administration indicators. Mentioned set of indicators was introduced 


\section{Tax burden index}

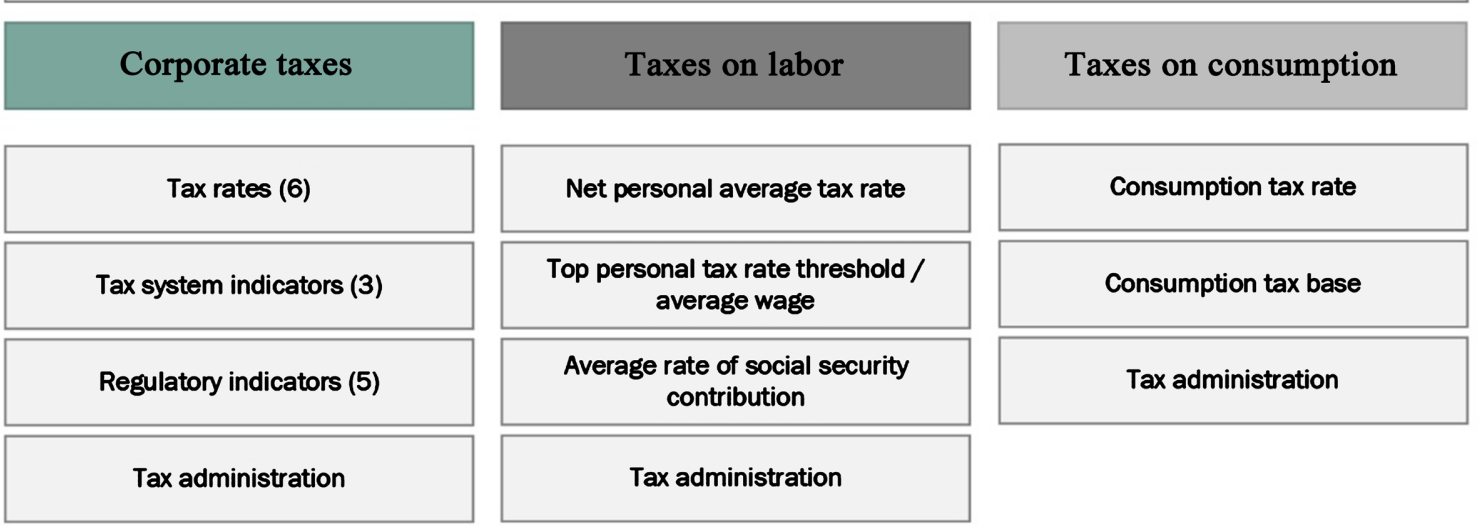

Figure 2. The estimation of the tax burden on the basis of the Tax burden index (compiled by author).

by Bunn and Asen (2020). The chosen valuation methodology is multicriteria and reflects the burden of different tax groups based on the EU's classification (see Figure 2).

After building the basics and methods for assessing the state financial stability and tax burden, a theoretical model of the impact of the tax burden on the state financial stability was constructed as presented in the next section.

\section{The Methodology for Assessing the Impact of Tax Burden on State Financial Stability}

The complexity of the model is revealed through different levels of state financial stability and tax burden assessment. The model has been designed for applicability in an international environment and is therefore suitable for research in individual regions or groups of countries. The impact assessment methodology uses a linear multivariate regression equation, hierarchical clustering and other econometric/statistical methods (Figure 3). These research methods have been chosen as reliable instruments for the purpose and scope of this paper and are generally recommended by the scientific literature for the investigation of the effects and causal relationships between variables. The interaction between the tax burden and financial stability in the 28 European Union member states was chosen as the main object of this paper. This group was chosen due to the relevance of the problem to the European Union, whose member states have differing tax systems and varying levels of financial market and economic development.

In order to determine the level of financial stability of the EU member states during the period of 2005-2019 the values of the indices assessing the stability of public finances, the stability of the financial system and the stability of the economy and their indicators were calculated. The tax burden has been determined according to the values of the tax burden assessment criteria for each member state. According to the following index values and using the hierarchical 

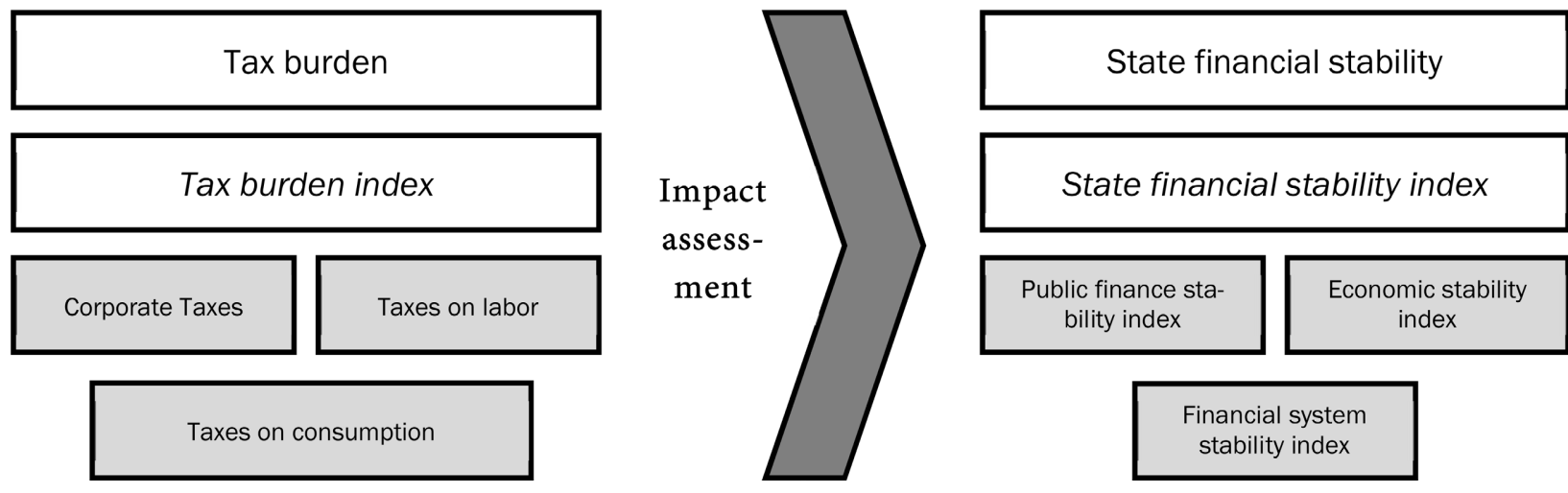

Figure 3. The model for assessing the impact of the tax burden on state financial stability (compiled by author).

Ward connection method the countries have been divided into 4 groups according to the hierarchical clustering analysis:

1) High tax burden and high financial stability (HTBHFS cluster);

2) Low tax burden and high financial stability (LTBHFS cluster);

3) High tax burden and low financial stability (HTBLFS cluster);

4) Low tax burden and low financial stability (LTBLFS cluster).

The impact of the tax burden on the state financial stability has been examined using multiple linear regression analysis (see equation provided below). During analysis regression models were formed for each indicator (dependent variable $-Y_{k}$ ) of public finance stability index, financial system stability index and economic stability index using time series data of each cluster. Regression models are provided in appendices of the paper (Tables A1-A3). Tax burden was used as one of the independent variables $\left(x_{k}, y_{k}, z_{k}, \cdots\right)$, therefore coefficients $(\beta)$ of tax burden variables in the regression models were selected as measure of impact. In cases when statistically significant models were formed only without independent variable of tax burden, it was considered that tax burden has no impact to the dependent variable, e.g. indicator, which is used in calculation of public finance stability, financial system stability or economic stability indexes. Using coefficients assigned to independent variables of tax burden impact to public finance stability, financial system stability and economic stability was calculated according to weights of indicators in the indices (Table A3). Finally, using data of impact to indices, tax burden impact to state financial stability was calculated (Table 1).

$$
Y_{k}=c+\beta_{1} x_{k}+\beta_{2} y_{k}+\beta_{3} z_{k}+\cdots+\varepsilon_{k}
$$

$$
\begin{aligned}
& c \text {-constant; } \\
& x_{k}, y_{k}, z_{k}, \ldots \text {-independent variables, } \\
& Y_{k}-\text { dependent variable, } \\
& \beta \text {-coefficients (parameters) of independent variables, } \\
& \varepsilon_{k} \text {-error term. }
\end{aligned}
$$

Publicly available data from the World Bank, the Organization for Economic Co-operation and Development (OECD), the ECB European Central Bank (2019) 
Table 1. Coefficients of (independent) tax burden variable in regression models of indices indicators.

\begin{tabular}{|c|c|c|c|c|}
\hline Public finance stability Index & & & & \\
\hline Indicator & HTBLFS & LTBHFS & HTBHFS & LTHLFS \\
\hline Bond yields & 0.01258 & 0.02271 & -0.01241 & 0.01025 \\
\hline Central government debt & -0.00069 & 0.00040 & 0.00306 & 0.00039 \\
\hline $\begin{array}{l}\text { Interest expenditure on } \\
\text { government revenue }\end{array}$ & 0.01422 & 0.00689 & -0.00843 & 0.01073 \\
\hline GDP & - & 0.00056 & -0.00100 & -0.00795 \\
\hline \multirow[t]{2}{*}{ Reserves/imports } & 0.00384 & -0.00044 & -0.00761 & -0.00221 \\
\hline & 0.02995 & 0.03011 & -0.02639 & 0.01122 \\
\hline \multicolumn{5}{|l|}{ Financial system stability index } \\
\hline Indicator & HTBLFS & LTBHFS & HTBHFS & LTHLFS \\
\hline Loans/GDP & - & 0.00003 & -0.00002 & -0.00033 \\
\hline Budget deficit/surplus & 0.00062 & - & 0.00284 & 0.00037 \\
\hline Private Sector Loans & 0.00003 & - & -0.00050 & - \\
\hline Non-performing loans & - & 0.00056 & -0.00053 & 0.00159 \\
\hline Z-score indicator & - & 0.00015 & -0.00004 & 0.00017 \\
\hline \multirow[t]{2}{*}{ Liquidity indicators } & - & 0.00009 & 0.00045 & -0.00458 \\
\hline & 0.00065 & 0.00083 & 0.00221 & -0.00279 \\
\hline \multicolumn{5}{|l|}{ Economic stability index } \\
\hline Indicator & HTBLFS & LTBHFS & HTBHFS & LTHLFS \\
\hline GDP (difference to target) & -0.00048 & - & 0.00143 & -0.00026 \\
\hline Unemployment rate & -0.00140 & 0.00029 & -0.00114 & -0.00155 \\
\hline Budget deficit & 0.00074 & - & 0.00341 & 0.00044 \\
\hline \multirow[t]{2}{*}{ Bond yields } & 0.00140 & 0.00760 & 0.00847 & 0.00140 \\
\hline & 0.00026 & 0.00789 & 0.01218 & 0.00005 \\
\hline Tax burden on state financial stability & 0.03086 & 0.03884 & -0.01200 & 0.00848 \\
\hline
\end{tabular}

(ECB), Eurostat, CESIF and other internationally recognized organizations were used in the study. Data were processed with MS Excel and IBM SPSS 24.

\section{The Generalised Results of the Regression Models}

The regression equations for the indicators (Annexes: Tables A1-A3) of the indices of the stability of the public sector, the financial system and the economy allowed us to calculate the overall impact of the change in the tax burden on the state financial stability. Table 1 shows the changes in the state stability indices after the increase of the tax burden. It can be observed that the increase in the 
tax burden would have a positive impact on the public finance stability in all groups of countries except the one with high tax burdens and high financial stability, where the negative impact would be relatively weak and would have little effect on the stability of public finance. The strongest positive impact was due to the positive developments of the bond yields and interest expenditure on government revenue, while the negative impact was strongest in conjunction with reserves/imports ratio.

The increase in tax burden has a positive effect on the stability of the financial system in all country groups except the one with low tax burdens and low financial stability. The biggest positive impact of the tax burden on the financial system stability is made through the reduction of the budget deficit ratio. The results of the study show that economic stability indicators would be positively affected by an increase in the tax burden in all country groups. The tax burden would also have the strongest impact on economic stability in a group of countries with high financial stability. The strongest negative value could be observed in conjunction with the difference to the nominal GDP, the change of which with the increase of the tax burden would have a negative impact on the stability of the economy. After assessing the impact of the tax burden on individual components of the state financial stability the total impact of the increase in the tax burden on the state financial stability could be calculated. According to the results of the empirical study the increase in tax burden strengthened state financial stability in three country groups, while decreased in the high tax stability/high financial stability country group.

The results of the empirical study allowed confirming 4 and rejecting 8 hypotheses (Table 2).

\section{Conclusion}

Taxation is one of the potential determinants of the state financial stability identified in the literature and in the empirical models. Regarding the methodological and socio-cultural context, the existing models differ in the expected impact of the taxation, and the results of the empirical studies are mixed and not conclusive.

We analysed the impact of the tax burden on state financial stability in $28 \mathrm{EU}$ countries in the period 2005-2019. To summarize, we can say that taxation may affect state financial stability in several ways through impact on economic growth, public finance stability and financial system stability. The intensity and direction of the impact are related to several conditions and depend on countries' tax burden and financial stability level.

In general, when the taxation is measured using tax burden index, an increase in tax burden would have a positive impact on the state financial stability in all country groups except the group with high tax burden and high financial stability. More concretely, the strongest positive impact is identified in high tax burden/low financial stability and low tax burden/high financial stability country groups, and the weakest one is in low tax burden/low financial stability country groups. 
Table 2. The confirmation and rejection of hypotheses.

\begin{tabular}{|c|c|c|c|}
\hline & TESTED HYPOTHESIS & RESULT & ARGUMENTATION \\
\hline $\mathrm{H} 1$ & $\begin{array}{l}\text { The tax burden has a significant } \\
\text { impact on the HTBLFS (High Tax } \\
\text { Burden/Low Financial Stability) } \\
\text { group: } \\
\mathrm{H}_{1} \text { has a positive (+) effect } \\
\mathrm{H}_{2} \text { has a negative (-) effect } \\
\mathrm{H}_{3} \text { significant impact not } \\
\text { determined }\end{array}$ & $\begin{array}{l}\text { Accepted } \\
\mathrm{H1}_{1} \text { has a positive }(+) \text { effect } \\
\text { Rejected } \\
\mathrm{H}_{2} \text { has a negative }(-) \text { effect } \\
\text { Rejected } \\
\mathrm{H}_{3} \text { significant impact not } \\
\text { determined }\end{array}$ & $\begin{array}{l}\text { The tax burden has a significant positive impact on } \\
\text { state financial stability for the HTBLFS (High Tax } \\
\text { Burden/Low Financial Stability) countries: } \\
\text { A positive effect of the tax burden for this group was } \\
\text { found in all indices. The tax burden influence to } \\
\text { Financial system stability index has the lowest positive } \\
\text { effect on HTBLFS ( } 0.00026 \text { ) group countries compared } \\
\text { to other countries groups, which also have a positive } \\
\text { effect ( } 0.00083 \text { in LTBHFS and } 0.00221 \text { in HTBHFS). }\end{array}$ \\
\hline $\mathrm{H} 2$ & $\begin{array}{l}\text { The tax burden has a significant } \\
\text { impact on the LTBHFS (Low Tax } \\
\text { Burden/High Financial Stability) } \\
\text { group: } \\
\mathrm{H}_{1} \text { has a positive (+) effect } \\
\mathrm{H}_{2} \text { has a negative (-) effect } \\
\mathrm{H}_{3} \text { significant impact not } \\
\text { determined }\end{array}$ & $\begin{array}{l}\frac{\text { Accepted }}{H_{1}} \text { has a positive }(+) \text { effect } \\
\text { Rejected } \\
\mathrm{H}_{2} \text { has a negative }(-) \text { effect } \\
\text { Rejected } \\
\mathrm{H}_{3} \text { significant impact not } \\
\text { determined }\end{array}$ & $\begin{array}{l}\text { The tax burden has a significant positive impact on } \\
\text { state financial stability for the LTBHFS (Low Tax } \\
\text { Burden/High Financial Stability) group: } \\
\text { This country group had the most indicators (10) with } \\
\text { positive effects compared to other groups of countries, } \\
\text { which was determined by the positive change in all } \\
\text { three state financial stability indices. In the LTBHFS } \\
\text { countries, the impact of the tax burden has the highest } \\
\text { positive effect on public finance ( } 0.03011 \text { ) and } \\
\text { economic stability (0.00789) between all country } \\
\text { groups. }\end{array}$ \\
\hline $\mathrm{H} 3$ & $\begin{array}{l}\text { The tax burden has a significant } \\
\text { impact on the HTBHFS (High Tax } \\
\text { Burden/High Financial Stability) } \\
\text { group: } \\
\mathrm{H}_{1} \text { has a positive (+) effect } \\
\mathrm{H}_{2} \text { has a negative (-) effect } \\
\mathrm{H}_{3} \text { significant impact not } \\
\text { determined }\end{array}$ & $\begin{array}{l}\text { Rejected } \\
H 3_{1} \text { has a positive }(+) \text { effect } \\
\frac{\text { Accepted }}{H 3_{2}} \underline{\text { has a negative }(-) \text { effect }} \\
\text { Rejected } \\
H_{3} \text { significant impact not } \\
\text { determined }\end{array}$ & $\begin{array}{l}\text { The negative impact of the tax burden for this country } \\
\text { group is found only in the Public finance stability } \\
\text { index (- } 0.02639) \text {. However, the negative impact is } \\
\text { stronger than the cumulative positive impact of } \\
\text { Financial system stability }(0.00221) \text { and Economic } \\
\text { stability ( } 0.01218) \text { indices, even considering that } \\
\text { between all countries groups both indices have the } \\
\text { highest positive effect in HTBHFS countries. }\end{array}$ \\
\hline $\mathrm{H} 4$ & $\begin{array}{l}\text { The tax burden has a significant } \\
\text { impact on the LTBLFS (Low Tax } \\
\text { Burden/Low Financial Stability) } \\
\text { group: }\end{array}$ & $\begin{array}{l}\text { Accepted } \\
H_{1} \text { has a positive }(+) \text { effect } \\
\text { Rejected } \\
\mathrm{H}_{2} \text { has a negative }(-) \text { effect } \\
\text { Rejected } \\
\mathrm{H}_{3} \text { significant impact not } \\
\text { determined }\end{array}$ & $\begin{array}{l}\text { The tax burden has a significant positive impact on } \\
\text { state financial stability for the LTBLFS (Low Tax } \\
\text { Burden/Low Financial Stability) countries. } \\
\text { A positive effect is found for the Public finance } \\
\text { stability index and the Economic stability index, but a } \\
\text { negative impact on Financial system stability } \\
\text { (-0.00279). Tax burden positively influences Economic } \\
\text { stability in all country groups, but the lowest effect is } \\
\text { found in LTBLFS countries }(0.00005) \text {. }\end{array}$ \\
\hline
\end{tabular}


According to our estimation with regards to the state financial stability index, an increase in the tax burden would have a positive effect on the economic stability in all country groups. The strongest positive impact was identified because of positive changes in bond yields and interest expenditure on government revenue indicators, the strongest negative impact was identified through the reserves/imports ration indicator. In addition, our results show a negative impact of increased taxation on public finance stability in high tax burden/high financial stability countries and positive in all other countries groups. On the contrary, the effect on financial system stability is negative only in low tax burden/low financial stability countries and positive in all remaining country groups (high tax burden/low financial stability, low tax burden/high financial stability, high tax burden/high financial stability).

These results can be also interpreted in terms of policy, as the impact of the variables differs depending on the distribution of the taxation/financial stability level. Hence, policymakers should adopt different strategies or financial stability policies to improve the design and effects of the tax burden in Europe. Finally, as future extensions of this research, it would be interesting to replicate the study using other statistical methods, for example, the quantile regression method, or with information regarding the reforms approved in the last years.

\section{Conflicts of Interest}

The author declares no conflicts of interest regarding the publication of this paper.

\section{References}

Abuselidze, G. (2012). The Influence of Optimal Tax Burden on Economic Activity and Production Capacity. Intellectual Economics, 6, 493-503.

Adam, A., Kammas, P., \& Lapatinas, A. (2015). Income Inequality and the Tax Structure: Evidence from Developed and Developing Countries. Journal of Comparative Economics, 43, 138-154. https://doi.org/10.1016/j.jce.2014.05.006

Akins, B., Li, L., Ng, J., \& Rusticus, T. O. (2016). Bank Competition and Financial Stability: Evidence from the Financial Crisis. Journal of Financial and Quantitative Analysis, 51, 1-28. https://doi.org/10.1017/S0022109016000090

Albulescu, C. (2010). Forecasting the Romanian Financial System Stability Using a Stochastic Simulation Model. Romanian Journal of Economic Forecasting, 13, 81-98.

Albulescu, C. (2012). Financial Stability, Monetary Policy and Budgetary Coordination in EMU. Theoretical \& Applied Economics, 19, 85-96.

Alshubiri, F. (2019). Public Finance Indicators and the Value of Investment Project Development: A Comparative Study of GCC Countries. Journal of Business Economics and Management, 20, 1143-1167. https://doi.org/10.3846/jbem.2019.10783

Alstadsaeter, A., Johannesen, N., \& Zucman, G. (2017). Tax Evasion and Inequality. National Bureau of Economic Research, Working Paper, No. 23772. https://doi.org/10.2139/ssrn.3109300

Amadeo, K. (2013). Budget Deficit. How Deficits Affect the Economy. 
http://useconomy.about.com/od/glossary/g/Budget_Deficit.htm

Birskyte, L. (2019). The Impact of Government Debt on Public Finance Stability in Lithuania. In Contemporary Issues in Business, Management and Economics Engineering' 2019, VGTU (pp. 296-303). International Scientific Conference.

Bischof, J., Laux, C., \& Leuz, C. (2019). Accounting for Financial Stability: Lessons from the Financial Crisis and Future Challenges. SAFE Working Paper Series 283, Leibniz Institute for Financial Research SAFE. https://doi.org/10.2139/ssrn.3393148

Blommestein, H. J., \& Turner, P. (2012). Interactions between Sovereign Debt Management and Monetary Policy under Fiscal Dominance and Financial Instability. OECD Working Papers on Sovereign Borrowing and Public Debt Management No. 3. OECD Publishing.

Bösenberg, S. P., Egger, \& Zoller-Rydzek, B. (2018). Capital Taxation, Investment, Growth, and Welfare, International Tax and Public Finance, 25, 352-376. https://doi.org/10.1007/s10797-017-9454-3

Boyd, J., Kwak, S., \& Smith, B. (2005). The Real Output Losses Associated with Modern Banking Crises. Journal of Money, Credit and Banking, 37, 977-999.

https://doi.org/10.1353/mcb.2006.0002

Bunn, D., \& Asen, E. (2020). International Tax Competitiveness Index 2020. Tax Foundation.

Caner, M., Grennes, T., \& Koehler-Geib, F. (2010). Finding the Tipping Point-When Sovereign Debt Turns Bad. Policy Research Working Paper 5391, The World Bank. https://doi.org/10.1596/1813-9450-5391

Celikay, F. (2020). Dimensions of Tax Burden: A Review on OECD Countries. Journal of Economics, Finance and Administrative Science, 25, 27-43. https://doi.org/10.1108/JEFAS-12-2018-0138

Cural, M., \& Cevik, N. K. (2015). Ekonomik kalkınmanın vergi yapısı üzerindeki etkisi: 1924-2013 dönemi Türkiye örnegi. Amme Idaresi Dergisi, 48, 127-158.

Das, U. S., Xu, T., \& Hu, K. (2019). Bank Profitability and Financial Stability. International Monetary Fund, Project: Systemic Risk and Financial Stability, Working Papers 19(5). https://doi.org/10.5089/9781484390078.001

Daugèlienè, R. (2012). Hypothetical of Macroeconomic Stability Surveillance Indicators and European Union's Initiatives for Maintenance of Financial Stability. European Integration Studies, No. 6.

Dell'Ariccia, G., Detragiache, E., \& Rajan, R. (2008). The Real Effect of Banking Crises. Journal of Financial Intermediation, 17, 89-112.

https://doi.org/10.1016/j.jfi.2007.06.001

Durusu-Ciftci, D., Gokmenoglu, K. K., \& Yetkiner, H. (2018). The Heterogeneous Impact of Taxation on Economic Development: New Insights from a Panel Cointegration Approach. Economic Systems, 42, 503-513. https://doi.org/10.1016/j.ecosys.2018.01.001

ECB European Central Bank (2019). Financial Stability Review. https://www.ecb.europa.eu/home/html/index.en.html

Fedec, A. (2009). Trading Economics 2. https://tradingeconomics.com/country-list/rating

Fell, J., \& Schinasi, G. (2005). Assessing Financial Stability: Exploring the Boundaries of Analysis. National Institute Economic Review, 192, 102-117. https://doi.org/10.1177/002795010519200110

Flood, M. D., Jagadish, H. V., \& Raschid, L. (2016). Big Data Challenges and Opportunities in Financial Stability Monitoring. Banque de France, Financial Stability Review, 20, 
129-142.

Gadanetz, B. K., Tsatsaronis, K., \& Altunbas, Y. (2012). Spoilt and Lazy: The Impact of State Support on Bank Behavior in the International Loan Market. International Journal of Central Banking, 8, 121-173.

Gersl, A., \& Hermanek, J. (2006). Financial Stability Indicators: Advantages and Disadvantages of Their Use in the Assessment of the Financial System Stability. Financial Stability Report, Czech National Bank.

Gray, D., Merton, R., \& Bodie, Z. (2007). New Framework for Measuring and Managing Macro Financial Risk and Financial Stability No. 13607. National Bureau of Economic Research.

Haldane, A., Aukman, D., Kapadia, S., Hinterschweiger, M. (2017). Rethinking Financial Stability. In Rethinking Macroeconomic Policy IV Conference (Paper No. 712). Bank of England-Staff Working. http://financial-stability.org/rethinking-financial-stability/

Hawkins, J., \& Klau, M. (2000). Measuring Potential Vulnerabilities in Emerging Market Economies, Bank for International Settlements. Monetary and Economic Department. https://doi.org/10.2139/ssrn.849258

Houben, A., \& Kakes, J. (2004). Toward a Framework for Safeguarding Financial Stability. IMF Working Paper No. WP/04/101. https://doi.org/10.5089/9781451852547.001

Houben, A., Kakes, J., \& Schinasi, G. (2005). A Practical Approach to Financial Stability. The Financial Regulator, 9, 70-77.

Ilgun, M. F. (2016). Financial Development and Domestic Public Debt in Emerging Economies: A Panel Cointegration Analysis. Journal of Applied Economics and Business Research, 6, 284-296.

Janda, K., \& Kravtsov, O. (2017). Time-Varying Effects of Public Debt on the Financial and Banking Development in Central and Eastern Europe (pp. 1-17). Munich Personal RePEc Archive, 77325.

Jiang, L., \& Levine, R. (2019). Does Competition Affect Bank Risk? https://faculty.haas.berkeley.edu/ross_levine/Papers/Bank\%20Risk_02_2019.pdf

Karagianni, S., Pempetzoglou, M., \& Saraidaris, A. (2012). Average Tax Rates and Economic Growth: A Nonlinear Causality Investigation for the USA. Frontiers in Finance and Economics, 12, 51-59.

Keller, S., \& Schanz, D. (2013). Tax Attractiveness and the Location of German-Controlled subsidiaries. Arqus Discussion Paper, No. 142, Arbeitskreis Quantitative Steuerlehre (Arqus), Berlinb. https://doi.org/10.2139/ssrn.2368713

Kotlán, I., \& Machová, Z. (2012a). The Influence of Corporate Taxation on Economic Growth: The Failure of Tax Quota? Politická Ekonomie, 60, 743-763. https://doi.org/10.18267/j.polek.875

Kotlán, I., \& Machová, Z. (2012b). World Tax Index: Methodology and Data. Danube: Law and Economics Review, 3, 19-33.

Kroszner, R., Laeven, L., \& Klingebiel, D. (2007). Banking Crises, Financial Dependence, and Growth. Journal of Financial Economics, 84, 187-228. https://doi.org/10.1016/j.jfineco.2006.05.001

Levine, R., \& Corbae, D. (2018). Competition, Stability, and Efficiency in the Banking Industry. https://faculty.haas.berkeley.edu/ross_levine/Papers/CorbaeLevine102118.pdf

Liu, L., \& Altshuler, R. (2013). Measuring the Burden of the Corporate Income Tax under Imperfect Competition. National Tax Journal, 66, 215-238. 
https://doi.org/10.17310/ntj.2013.1.08

Mao, C. (2017). Growth, Income Inequality, and Capital Income Taxes. Economics Bulletin, 36, 1463-1478.

Milasi, S., \& Waldmann, R. J. (2018). Top Marginal Taxation and Economic Growth. Applied Economics, 50, 2156-2170. https://doi.org/10.1080/00036846.2017.1392001

Nelson, W. R., \& Perli, R. (2007). Selected Indicators of Financial Stability. Risk Measurement and Systemic Risk, 4, 343-372.

OECD (2019). Tax Revenue Trends in the OECD. Revenue Statistics 2019.

Ozili, P. K. (2020). Tax Evasion and Financial Instability. Journal of Financial Crime, 27, 531-539. https://doi.org/10.1108/JFC-04-2019-0051

Ozili, P. K., \& Thankom, A. G. (2018). Income Smoothing among European Systemic and Non-Systemic Banks. The British Accounting Review, 50, 539-558.

Paientko, T., \& Oparin, V. (2020). Reducing the Tax Burden in Ukraine: Changing Priorities. Central European Management Journal, 28, 98-126.

https://doi.org/10.7206/cemj.2658-0845.28

Riley, G. (2009). Macroeconomic Stability. https://www.tutor2u.net/economics

Riley, G. (2014). Macroeconomics. Tutor2ru.

Roosma, F., Oorschot, W., \& Gelissen, J. (2015). A Just Distribution of Burdens? Attitudes toward the Social Distribution of Taxes in 26 Welfare States. International Journal of Public Opinion Research, 28, 376-400. https://doi.org/10.1093/ijpor/edv020

Salaudeen, Y., \& Atoyebi, T. (2018). Tax Burden Implication of Tax Reform. Open Journal of Business and Management, 6, 761-777. https://doi.org/10.4236/ojbm.2018.63058

Schakeldorf, D. A., Slemrod, J., \& Sallee, J. M. (2011). Financial Reporting, Tax, and Real Decisions: Toward a Unifying Framework. International Tax and Public Finance, 18, 461-492. https://doi.org/10.1007/s10797-011-9176-x

Schinasi, G. J. (2006). Safeguarding Financial Stability: Theory and Practice. International Monetary Fund.

Sharuddin, D., \& Rama, A. (2017). Currency System and Its Impact on Economic Stability. Journal Ilmu Ekonomi Syariah (Journal of Islamic Economics), 9, 289-310.

https://doi.org/10.15408/aiq.v9i2.4749

Skarzauskas, S. (2016). Influence of Tax Burden on Countries Financial Stability. In Proceedings of 4th International Symposium of Business System Laboratory (pp. 189-192). 24-26August 2016, Vilnius, Lithuania.

Staniuliene, G. (2015). Fiskaliniu kintamujų poveikio finansiniam stabilumui vertinimas. Doctoral Thesis, Vilnius.

Tamai, T., \& Myles, G. (2019). Unemployment, Tax Competition and Tax Transfer Policy (pp. 1-25). Economic Research Center.

Valenduc, C. (2019). Corporate Income Tax in the EU, the Common Consolidated Corporate Tax Base (CCCTB) and Beyond: Is It the Right Way to Go? ETUI Research Paper-Working Paper 2018.06. https://doi.org/10.2139/ssrn.3316120

Van den End, J. (2006). Indicator and Boundaries of Financial Stability. No. 097, Netherlands Central Bank, Research Department.

Vasileva, T. (2020). Tax Burden as an Indicator of Assessing the Impact of Taxation System on Region's Economy. In Advances in Social Science, Education and Humanities Research (Vol. 392, pp. 411-414). Atlantis Press.

https://doi.org/10.2991/assehr.k.200113.085 
Vasiliauskaite, A., \& Stankevičius, E. (2009). Tax Burden Management and GDP Growth: Case of EU. Ekonomika ir vadyba: 2009. 14.

Yanikkaya, H., \& Turan, T. (2018). Tax Structure and Economic Growth: Do Differences in Income Level and Government Effectiveness Matter? The Singapore Economic Review, 65, 217-237. https://doi.org/10.1142/S0217590818500170 


\section{Appendix}

Table A1. Regression models for indicators of public finance stability index.

\begin{tabular}{|c|c|c|c|c|c|c|c|c|}
\hline $\begin{array}{l}\text { Dependent } \\
\text { variable }\end{array}$ & Group & Constant & \multicolumn{4}{|c|}{ Coefficients of independent variables } & $\mathbf{R}^{2}$ & Sign. F \\
\hline \multirow{5}{*}{$\begin{array}{l}\text { Bond yields } \\
\text { (rev.) }\end{array}$} & & $\mathrm{C}$ & Tax burden & $\begin{array}{l}\text { Nominal } \\
\text { GDP }\end{array}$ & $\begin{array}{c}\text { Gover. debt } \\
\text { (rev.) }\end{array}$ & & & \\
\hline & HTBLFS & -4.03 & 6.29 & 0.43 & 0.90 & & 0.70 & 0.010 \\
\hline & LTBHFS & -5.81 & 11.35 & 0.05 & 0.26 & & 0.79 & 0.002 \\
\hline & HTBHFS & 4.60 & -6.21 & 0.16 & 0.12 & & 0.54 & $0.060^{*}$ \\
\hline & LTBLFS & -1.99 & 5.12 & 0.10 & 0.38 & & 0.68 & 0.013 \\
\hline \multirow{5}{*}{$\begin{array}{c}\text { Change of } \\
\text { central } \\
\text { government } \\
\text { debt (rev.) }\end{array}$} & & $\mathrm{C}$ & Tax burden & & GDP & & & \\
\hline & HTBLFS & 0.79 & -0.23 & & 0.22 & & 0.41 & $0.071^{\star}$ \\
\hline & LTBHFS & 0.55 & 0.13 & & 0.24 & & 0.48 & 0.037 \\
\hline & HTBHFS & 0.02 & 1.02 & & 0.17 & & 0.37 & $0.096^{*}$ \\
\hline & LTBLFS & 0.46 & 0.13 & & 0.39 & & 0.75 & 0.001 \\
\hline \multirow{5}{*}{$\begin{array}{l}\text { Interest } \\
\text { expenditure on } \\
\text { government } \\
\text { revenue (rev.) }\end{array}$} & & $\mathrm{C}$ & Tax burden & $\begin{array}{c}\text { Govern. debt } \\
\text { (rev.) }\end{array}$ & & & & \\
\hline & HTBLFS & -2.84 & 4.74 & 0.80 & & & 0.54 & 0.021 \\
\hline & LTBHFS & -1.07 & 2.30 & 0.71 & & & 0.77 & 0.001 \\
\hline & HTBHFS & 1.71 & -2.81 & 1.21 & & & 0.53 & 0.024 \\
\hline & LTBLFS & -1.67 & 3.58 & 0.81 & & & 0.38 & $0.098^{*}$ \\
\hline \multirow{5}{*}{ GDP per capita } & & $\mathrm{C}$ & Debt (rev.) & $\begin{array}{l}\text { Unemploy. } \\
\text { (+1 lag) }\end{array}$ & FDI/GDP & Loans/GDP & & \\
\hline & HTBLFS & -30.98 & -0.42 & 0.64 & 3.49 & 31.66 & 0.72 & 0.024 \\
\hline & LTBHFS & 0.60 & -0.10 & 1.32 & 0.64 & -1.04 & 0.60 & $0.084^{*}$ \\
\hline & HTBHFS & -26.40 & -2.59 & 2.29 & -3.89 & 28.53 & 0.64 & $0.062^{*}$ \\
\hline & LTBLFS & - & - & - & - & - & - & - \\
\hline \multirow{5}{*}{ Reserves/Import } & & $\mathrm{C}$ & Tax burden & $\begin{array}{c}\text { World } \\
\text { economic } \\
\text { index }\end{array}$ & $\begin{array}{l}\text { Nom. GDP } \\
\text { growth }\end{array}$ & & & \\
\hline & HTBLFS & -1.61 & 3.84 & 0.09 & -0.49 & & 0.74 & 0.006 \\
\hline & LTBHFS & -0.50 & -0.44 & 0.05 & -0.09 & & 0.56 & 0.050 \\
\hline & HTBHFS & 5.82 & -7.61 & -0.04 & -0.17 & & 0.60 & 0.033 \\
\hline & LTBLFS & 1.31 & -2.21 & 0.22 & -0.06 & & 0.80 & 0.002 \\
\hline
\end{tabular}


Table A2. Regression models for indicators of financial system stability index.

\begin{tabular}{|c|c|c|c|c|c|c|c|c|}
\hline \multirow{6}{*}{$\begin{array}{l}\text { Dependent } \\
\text { variable }\end{array}$} & \multirow{3}{*}{$\begin{array}{l}\text { Group } \\
\text { HTBLFS }\end{array}$} & \multirow{2}{*}{$\begin{array}{c}\text { Constant } \\
\text { C }\end{array}$} & \multicolumn{4}{|c|}{ Coefficients of independent variables } & \multirow[t]{2}{*}{$\mathbf{R}^{2}$} & \multirow[t]{2}{*}{ Sign. F } \\
\hline & & & $\begin{array}{l}\text { Unemp. } \\
\text { (+1 lag) }\end{array}$ & $\begin{array}{l}\text { Net interest } \\
\text { margin (rev.) }\end{array}$ & & & & \\
\hline & & 0.98 & 0.003 & -0.013 & & & 0.47 & 0.043 \\
\hline & LTBHFS & 0.82 & 0.10 & -0.01 & & & 0.82 & 0.000 \\
\hline & HTBHFS & 0.92 & 0.08 & 0.01 & & & 0.53 & 0.022 \\
\hline & LTBLFS & 0.58 & 0.47 & -0.02 & & & 0.65 & 0.006 \\
\hline \multirow{5}{*}{$\begin{array}{l}\text { Budget deficit } \\
\text { (rev.) }\end{array}$} & & $\mathrm{C}$ & $\begin{array}{c}\text { Tax } \\
\text { burden }\end{array}$ & & GDP & & & \\
\hline & HTBLFS & -0.57 & 1.12 & & 0.48 & & 0.61 & 0.009 \\
\hline & LTBHFS & - & - & & - & & - & - \\
\hline & HTBHFS & -3.06 & 5.12 & & 0.41 & & 0.47 & 0.040 \\
\hline & LTBLFS & -0.28 & 0.67 & & 0.57 & & 0.43 & $0.062^{*}$ \\
\hline \multirow{5}{*}{$\begin{array}{l}\text { Loans to private } \\
\text { sector/Nominal } \\
\text { GDP }\end{array}$} & & $\mathrm{C}$ & $\begin{array}{l}\text { Real GDP } \\
\text { growth }\end{array}$ & $\begin{array}{l}\text { Net interest } \\
\text { margin (rev.) }\end{array}$ & $\begin{array}{l}\text { Unempl. } \\
\text { (+1 lag) }\end{array}$ & & & \\
\hline & HTBLFS & - & - & - & - & & - & - \\
\hline & LTBHFS & - & - & - & - & & - & - \\
\hline & HTBHFS & 0.27 & 0.23 & -0.25 & 0.39 & & 0.93 & 0.000 \\
\hline & LTBLFS & -0.15 & 0.01 & 0.40 & 0.70 & & 0.64 & 0.023 \\
\hline \multirow{5}{*}{$\begin{array}{l}\text { Non-performing } \\
\text { loans (rev.) }\end{array}$} & & $\mathrm{C}$ & $\begin{array}{l}\text { Real GDP } \\
\text { growth }\end{array}$ & $\begin{array}{l}\text { Net interest } \\
\text { margin (rev.) }\end{array}$ & Loans/GDP & & & \\
\hline & HTBLFS & 11.397 & 2.85 & -0.77 & -12.47 & & 0.84 & 0.001 \\
\hline & LTBHFS & -5.26 & 1.12 & -0.19 & 6.41 & & 0.89 & 0.000 \\
\hline & HTBHFS & - & - & - & - & & - & - \\
\hline & LTBLFS & 3.93 & 0.85 & -0.78 & 5.60 & & 0.81 & 0.001 \\
\hline \multirow{5}{*}{ Z-score } & & $\mathrm{C}$ & $\begin{array}{c}\text { Loans/GD } \\
\mathrm{P}\end{array}$ & $\begin{array}{l}\text { Net interest } \\
\text { margin (rev.) }\end{array}$ & Capital/assets & & & \\
\hline & HTBLFS & -0.12 & 0.35 & -0.16 & 0.32 & & 0.77 & 0.003 \\
\hline & LTBHFS & -4.16 & 4.76 & 0.22 & 0.67 & & 0.90 & 0.000 \\
\hline & HTBHFS & -2.59 & 2.69 & 0.59 & 0.54 & & 0.82 & 0.001 \\
\hline & LTBLFS & 0.64 & -0.50 & -0.04 & 0.60 & & 0.71 & 0.008 \\
\hline \multirow{5}{*}{ Liquidity ratio } & & $\mathrm{C}$ & $\begin{array}{l}\text { Non-perfor } \\
\text {.loans } \\
\text { (rev.) }\end{array}$ & $\begin{array}{l}\text { Net interest } \\
\text { margin (rev.) }\end{array}$ & Deposits/M3 & $\begin{array}{l}\text { Real GDP } \\
\text { gro. }\end{array}$ & & \\
\hline & HTBLFS & 0.21 & 0.27 & -0.14 & -0.11 & -0.13 & 0.72 & 0.024 \\
\hline & LTBHFS & 0.72 & 0.50 & 0.15 & -0.92 & -0.59 & 0.67 & 0.045 \\
\hline & HTBHFS & - & - & - & - & - & - & - \\
\hline & LTBLFS & -0.13 & 0.03 & 0.14 & -0.01 & 1.05 & 0.83 & 0.003 \\
\hline
\end{tabular}


Table A3. Regression models for indicators of economic stability index.

\begin{tabular}{|c|c|c|c|c|c|c|c|c|}
\hline $\begin{array}{c}\text { Dependent } \\
\text { variable }\end{array}$ & Group & Constant & Co & ficients of indeper & dent variabl & & $\mathbf{R}^{2}$ & Sign. F \\
\hline \multirow{5}{*}{$\begin{array}{l}\text { Real GDP } \\
\text { (diff. from } \\
\text { target value, } \\
\text { rev.) }\end{array}$} & & $\mathrm{C}$ & $\begin{array}{c}\text { Gover. debt } \\
\text { (rev.) }\end{array}$ & $\begin{array}{l}\text { Unempl. (+1 lag; } \\
\text { rev.) }\end{array}$ & FDI/GDP & Loans/GDP & & \\
\hline & HTBLFS & -1.79 & -0.85 & 0.85 & 0.45 & -2.44 & 0.77 & 0.012 \\
\hline & LTBHFS & - & - & - & - & - & - & - \\
\hline & HTBHFS & 36.86 & 2.35 & -1.38 & 16.34 & -40.18 & 0.74 & 0.019 \\
\hline & LTBLFS & -0.57 & -0.43 & 0.34 & 0.55 & 1.46 & 0.59 & $0.099^{*}$ \\
\hline \multirow{5}{*}{$\begin{array}{l}\text { Unemploy- } \\
\text { ment (rev.) }\end{array}$} & & $\mathrm{C}$ & $\begin{array}{c}\text { Real GDP } \\
\text { growth } \\
(-1 \text { lag })\end{array}$ & Tax burden & FDI/GDP & & & \\
\hline & HTBLFS & 0.92 & -2.11 & 0.75 & 4.44 & & 0.79 & 0.002 \\
\hline & LTBHFS & -0.05 & 0.44 & 0.72 & 0.12 & & 0.89 & 0.000 \\
\hline & HTBHFS & 1.23 & 0.62 & 0.62 & 2.47 & & 0.74 & 0.006 \\
\hline & LTBLFS & 1.69 & -2.32 & 0.31 & -0.14 & & 0.76 & 0.004 \\
\hline \multirow{5}{*}{$\begin{array}{l}\text { Budget deficit } \\
\text { (rev.) }\end{array}$} & & $\mathrm{C}$ & Tax burden & & GDP & & & \\
\hline & HTBLFS & -0.57 & 1.12 & & 0.48 & & 0.61 & 0.009 \\
\hline & LTBHFS & - & - & & - & & - & - \\
\hline & HTBHFS & -3.06 & 5.12 & & 0.41 & & 0.47 & 0.040 \\
\hline & LTBLFS & -0.28 & 0.67 & & 0.57 & & 0.43 & $0.062^{\star}$ \\
\hline \multirow{5}{*}{$\begin{array}{l}\text { Bond yield } \\
\quad \text { (rev.) }\end{array}$} & & $\mathrm{C}$ & Tax burden & $\begin{array}{l}\text { Real GDP } \\
\text { growth }\end{array}$ & $\begin{array}{l}\text { Gover. debt } \\
\text { (rev.) }\end{array}$ & & & \\
\hline & HTBLFS & -3.06 & 4.24 & 0.22 & 2.27 & & 0.72 & 0.007 \\
\hline & LTBHFS & -2.08 & 3.80 & 0.08 & 1.05 & & 0.54 & $0.061^{\star}$ \\
\hline & HTBHFS & -0.40 & 0.70 & 0.11 & 0.85 & & 0.63 & 0.024 \\
\hline & LTBLFS & 0.51 & 0.70 & 0.17 & 0.48 & & 0.52 & $0.077^{\star}$ \\
\hline
\end{tabular}

